\title{
CNTNAP1 wt Allele
}

National Cancer Institute

\section{Source}

National Cancer Institute. CNTNAP1 wt Allele. NCI Thesaurus. Code C51341.

Human CNT NAP1 wild-type allele is located within 17q21 and is approximately $17 \mathrm{~kb}$ in length. This allele, which encodes contactin-associated protein 1, plays a role in signal transduction and in the recruitment and activation of intracellular signaling pathways in neurons. 